\title{
O africanista
}

\author{
SOTER BARRETO
}

Isu tirou de trás da orelha meio viddi e depois de cuidadosamente limpá-lo colocou-o na boca. Riscou um fósforo e acendeu-o. Inspirou profundamente, revelando a sua dentadura estragada. Na verdade, aqueles dentes podres e aquela ponta de viddi pareciam feitos um para outro.

Alsu era paddecar, um apanhador de cocos da aldeia. Hoje a colheita de cocos tinha sido boa. Depois de ter ido a casa lavar-se dos pés à cabeça, foi para o gaddhi de Kistu. Neste dia tinha algo de especial para Ihe perguntar. Espera, disse gaddhi? Arrecha! Antigamente podia-se chamar gaddhi sem problemas. Mas agora não era apenas um pecado, era pecado mortal. Tal como outros gaddhis tinha-se transformado num bar - "Bar and Restaurant Vailankanni".

Mas para Alsu e para os outros paddecares e trabalhadores braçais da aldeia, continuava a ser o gaddhi de Kistu como nos velhos tempos. Eles reuniam-se lá, bebendo e dando à língua, e assim se passava o tempo. Mas uma coisa já tinha mudado - o bar agora pertencia ao filho do velho Kistu, que também se chamava Christopher, ou Kistu para abreviar.

Como já disse, Alsu tinha algo a perguntar a Kistu, uma dúvida que o inquietava, e que só o dono do bar era capaz de esclarecer. Na verdade, Kistu era o guardião de todos os pequenos e grandes segredos da aldeia e um poço inesgotável de informações. Um dia as fontes de Kesarval e Torsam poderão estancar mas o manancial de revelações de Kistu nunca secaria. Um bocado medricas por natureza, hoje Alsu estava resoluto: iria tirar aquela questão a limpo. Mas primeiro precisava de molhar a garganta e de aquecer a barriga. Para ganhar coragem ele pediu: "Kistu, um pav de alem, se faz favor". 
Segurando o pav de fenim de coco com gengibre, Kistu ia apanhar uma garrafa de soda com a outra mão, mas Alsu disse-Ihe: "Não, não! Hoje nada de soda para mim. Estou com a garganta irritada - acho que estou a ficar constipado".

Alsu hesitou: será que lhe podia dizer que a sua pergunta precisava de coragem, e que era por isso que ele não diluía a sua bebida? Xi! Tinha muita vergonha!

Fitando o encorpado e bem apessoado Kistu, que parecia o protagonista de um filme hindi, Alsu empinou o copo e tomou um bom trago do seu alem. Pela sua cara quase que dava para ver o caminho fogoso da aguardente pelas goelas abaixo até o fundo do estômago.

"Xi, Kistu. O teu alem é bem forte, re." Foram estas as palavras que Alsu conseguiu balbuciar depois de tossir com força e massajar a sua garganta.

"Claro, Alsu-bab! Não te dei uma porcaria qualquer. Esse alem é maduro. Está posto de parte. Só o tiro para ocasiões especiais e quando me der na gana", disse Kistu, enchendo o seu copo outra vez.

Uma coisa era certa. Se alguém da aldeia quisesse álcool da terra ou até do estrangeiro, era com Kistu que era preciso falar. Noutros tempos, quando o maior proprietário da aldeia, também conhecido como vhoddlo batcar ou africanista, queria vinho branco ou tinto, conhaque, uísque ou o que quer que fosse, ele ia entregar-lhe à casa. Kistu era muito prestável por natureza. Quando o batcar africanista estava fora, ele cuidava da sua casa e propriedade, até por ser seu vizinho. Só recentemente é que se tinha afastado um pouco. E a informação que Alsu queria saber era precisamente acerca dele!

Nesse preciso momento, dois dos seus companheiros paddecares, Ruzai e Sodu, chegaram e sentaram-se à sua mesa. Assim que os viu, Alsu sentiu-se mais confiante. $\mathrm{O}$ pav de alem já tinha assentado bem e aquecia o seu estômago. $\mathrm{Na}$ distância ouvia-se música. Sodu disse: "Parece que há festa em casa do batecar africanista. Esta música e aquelas luzes são da casa dele".

Ruzar olhou para Kistu em silêncio, enquanto Sodu retomou: "É por causa do novo filho do africanista, que acabou de nascer. Dia sim dia não festejam o acontecimento. E o mais incrível é que o pai já tem quase oitenta anos".

Alsu estava apenas à espera de uma desculpa para se introduzir na conversa. Alguma coisa ele já sabia do passado do africanista, mas não tanto como Kistu. O batecar era o maior proprietário da aldeia. Embora o seu verdadeiro nome fosse José Emerciano Teodósio de Castelo Branco e Dias, os aldeões chamavam- 
-no africanista e havia boas razões para essa alcunha. Ele tinha passado a maior parte da vida em Moçambique. A sua mãe, D. Telma, filha única do proprietário da aldeia, tinha-se apaixonado por um pacló português, como os brancos eram conhecidos, quando estudava no liceu. Ela fê-lo ghorzavoim, um genro que vive em casa do sogro. José Emerciano-bab, único filho deles, fora nomeado para um posto importante na administração colonial da África oriental portuguesa. Viveu lá uns bons anos. Depois da morte dos seus pais, e temendo que a casa e suas propriedades se degradassem, viu-se forçado a voltar para Goa já com idade avançada. Antes disso, era Kistu quem cuidava de todos os seus assuntos.

Contava-se que durante a sua juventude em África levou uma vida de estroina. Embora tivesse adentrado na má-vida até quase perder o pé, conseguia manter seco o langotim; mais picante ainda é que há dois anos atrás ele foi de férias e voltou casado. $\mathrm{E}$ a esposa que trouxe com ele era uma boneca de vinte e cinco anos, uma verdadeira beleza. Um ano mais tarde nasceu-lhes um rapaz. Hoje era aniversário dele, e daí a festa. Mas Kistu já não ia a casa deles como dantes.

Por esta altura, Alsu já tinha emborcado o segundo pav e queria ainda mais apaziguar a sua dúvida. Ele chamou Kistu num tom mais alto: "Kistu-bab, chega-te aqui. Tenho uma coisa importante para te perguntar. Arre! Tu conheces ao pormenor tudo aquilo que se passa na aldeia, não é?".

Já se via que Alsu estava meio borracho. Kistu pôs-se a pensar se não teria cometido um erro ao servir-lhe o seu alem mais maduro. Mesmo assim, colocou o pav de lado e perguntou: "Diz, Alsu, o que querias saber?".

"Olhe, Kistu-bab... O africanista está mesmo velho, não está?"

Kistu concordou.

"E a mulher do africanista é mesmo um bom pedaço, não é?"

Outra vez Kistu anuiu com a cabeça.

"Nesse caso, diz-me uma coisa. Numa idade daquelas, dá para fazer filhos tão... rapidamente?", disse ele, batendo na mesa com o punho. Por sorte, Ruzar, Sodu e Kistu conseguiram agarrar os copos e garrafas a tempo. Antes de Kistu ter tempo para responder, Ruzar entrou na conversa:

"E isso é estranho porquê? Dizem que homens e coqueiros dão frutos até morrer."

Alsu perdeu a cabeça. "Ruzar, ninguém pediu a tua opinião. Sim, Kistu, fala!", disse, encarando-o de novo. 
Kistu olhou em redor. Quis a sorte que mais ninguém nesse momento estava no bar salvo eles.

"Alsu, vou-te contar uma história. Ouve com atenção. É uma história africana, acerca de um caçador. Um dia foi passear na floresta sem levar consigo a sua espingarda. Tudo o que ele tinha era uma bengala. De repente, apareceu-lhe um tigre ao caminho. Petrificou, mas como era um bom caçador, não queria mostrar medo diante da fera. Instintivamente, levou a bengala ao ombro como se fosse uma arma e fez um 'dum!' com a boca. E o mais incrível é que o tigre caiu logo morto. $\mathrm{O}$ caçador pensou que o tigre tinha morrido de choque, por causa do barulho pavoroso que ele tinha feito. E passou a contar esta história a todos, cheio de orgulho. Mas a verdade era outra. Quando o caçador levou a bengala ao ombro e fez aquele ruído, escondido num arbusto, atrás dele, estava o homem que realmente tinha disparado o tiro."

O efeito do alem que o Alsu tinha disfrutado dissipava-se rapidamente.

"Se são pretos, meu amor,

Teu pai e tua mãezinha,

Como é que tu saíste

Branco tal como a farinha?

Senhor, não me queira mal

Por esta cor que é minha.

É que nasci sexta-feira,

noite de lua-cheinha."

Cantando esta canção, Alsu foi andando para casa. 